\title{
Influence of Water on Bonding of various Methacrylates to Dentin treated with $10 \%$ Citric Acid-3\% Ferric Chloride Solution
}

\author{
Tadao FUKUSHIMA and Takashi HORIBE \\ Department of Dental Materials and Devices, Fukuoka Dental College, 700 Ta, Sawara-ku, Fukuoka 814 \\ -01 , Japan
}

Received on July 31,1989

Accepted on March 20, 1990

The bond strength of resins (MMA-TBB resin system), containing 2-hydroxyethyl methacrylate (2HEMA), 3-methacryloyloxypropionic acid (3MPA), 2-phenylethyl methacrylate (Py1EM) and 2-(1-naphthy1) ethyl methacrylate (NEM), to dentin treated with a solution of $10 \%$ citric acid and $3 \%$ ferric chloride was measured after being immersed in water at $37^{\circ} \mathrm{C}$ for a long period of time to investigate the influence of water on bonding, and the relationship between the monomer structure and the decrease in bond strength in water. The bond strength of the resins did not change with the time spent immersed in water up to 6 months, but decreased with any further increase in time. The decrease in bond strength of all the resins tested was caused by either the degeneration and swelling of collagen or a difference in the degradation of the resin inside and outside the acid-proof dentin layer. There was no significant relationship between the decrease in bond strength in water and the monomer structure.

Key words: Methacrylate, Bond strength, Dentin

\section{INTRODUCTION}

A solution of $10 \%$ citric acid and $3 \%$ ferric chloride called $10-3$ solution, which was developed by Nakabayashi et al, greatly improved the bonding of the MMA-TBB resin system to dentin. ${ }^{1}$ Nakabayashi $e t a l{ }^{2}{ }^{2}$ suggested that the increase in bond strength was the result of the formation of an acid-proof dentin layer called resin-reinforced dentin. However, Nakabayashi et al. ${ }^{3}$ reported that the bond strength of the resins containing hydrophilic monomers such as 2-hydroxyethyl methacrylate (2-HEMA) and (2-phosphoryl) ethyl methacrylate rapidly decreased in water.

In a previous study ${ }^{4}$, Fukushima et al. measured the bond strength of resins (MMA-TBB resin system), containing various methacrylate monomers, to dentin treated with the 10-3 solution after immersion in water at $37^{\circ} \mathrm{C}$ for 1 day and 30 days. The bond strength of all the resins was more than $14.9 \mathrm{MPa}$ and did not differ statistically. In addition, the bond strength did not decrease with the time in water at $37^{\circ} \mathrm{C}$.

Kiyomura $^{5)}$ reported that the bond strength of 4-META/MMA-TBB resin to dentin treated with the 10-3 solution was greatly reduced by long-term water immersion. In this study, we therefore measured the bond strength of resins (MMA-TBB resin system), containing 2-HEMA, 3-methacryloyloxypropionic acid (3MPA), 2-phenylethyl methacrylate (PyIEM) and 2-(1-naphthyl) ethyl methacrylate (NEM), to dentin treated with the 10-3 solution after being immersed in water at $37^{\circ} \mathrm{C}$ for a long period of time to investigate in detail the relationship between the monomer structure and the decrease in bond strength in water. 


\section{MATERIALS AND METHODS}

\section{Preparation of monomers}

The monomers (3MPA, PylEM and NEM) were prepared by the reaction of 3hydroxypropionic acid, $\beta$-phenethyl alcohol and 2-(1-naphthyl) ethanol with methacryloyl chloride according to previously described methods ${ }^{6,7}$.

The structural formulae of 2-HEMA and the synthesized monomers are shown in Fig. 1. Preparation of bonding resins

Mixtures of 2-HEMA and the synthesized monomers ( 2 mol \%) with MMA were used as resin monomers. MMA alone was used as a control. A monomer liquid/PMMA powder* mixture was cured with TBB-O*.

Measurement of tensile bond strength

Freshly extracted bovine anterior teeth, as substitutes for human teeth, were used as adherents ${ }^{8}$. The enamel was removed with a diamond wheel under water coolant. The teeth were embedded in acrylic tubes with acrylic resin. The dentin surface was finely polished with 600-grit $\mathrm{SiC}$ paper under running water, and then etched with the 10-3 solution for 30 seconds. All of the etched dentin surfaces were washed with water for 10 seconds after etching. They were then dried with oil-free compressed air for 20 seconds.

Split-silicon packing with a 5-mm internal diameter was placed on the dried dentin surface. With a brush, the monomer liquid/PMMA powder mixture was applied to the dentin. Next, self-curing resin was placed over the cured resin and an acrylic rod with a retaining hole was pressed onto the self-curing resin. Upon curing and removing the packing, the specimens were immersed in water at $37^{\circ} \mathrm{C}$ for 1 day, 1 month, 6 months and 1 year.

Tensile bond tests were performed on a universal testing machine ${ }^{* *}$ at a crosshead speed of $1 \mathrm{~mm} / \mathrm{min}$ using an apparatus shown previously'). The mean bond strength was calculated from the results on 10 specimens. The results were analyzed by analysis of variance and by Scheffe's multiple comparison test at a significance level of 0.05 .

Scanning electron microscopic (SEM) observation

After the tensile bond tests, the dentin and resin surfaces were prepared for SEM

R:

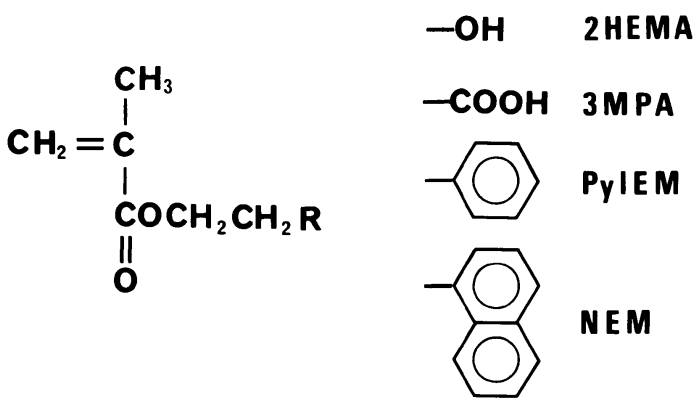

Fig. 1 Structural formulae of monomers.

* Sun Medical Co., Ltd., Kyoto, Japan

** IS-5000, Shimazu Co., Kyoto, Japan 
observation. The surfaces were coated with a thin layer of gold-palladium and were then observed under a SEM***.

\section{RESULTS}

There was no statistical difference in the bond strength among the resins after being immersed in water at $37^{\circ} \mathrm{C}$ for 1 month, 6 months and 1 year, although the bond strength of the resins containing 2-HEMA and synthesized monomers was statistically higher than that of the control after immersion in water at $37^{\circ} \mathrm{C}$ for 1 day $(\mathrm{P} \leq 0.05)$.

With the exception of the control, the bond strength of the resins did not change with the time in water up to 6 months, but decreased with any further increase in time (Fig. 2).

Figures 3 and 4 show the typical fractured resin and dentin surfaces after the tensile bond tests. The specimen immersed for 1 day showed resin cohesive fractures and dentin cohesive fractures. The specimen immersed for 1 year showed resin cohesive fractures, resin-dentin

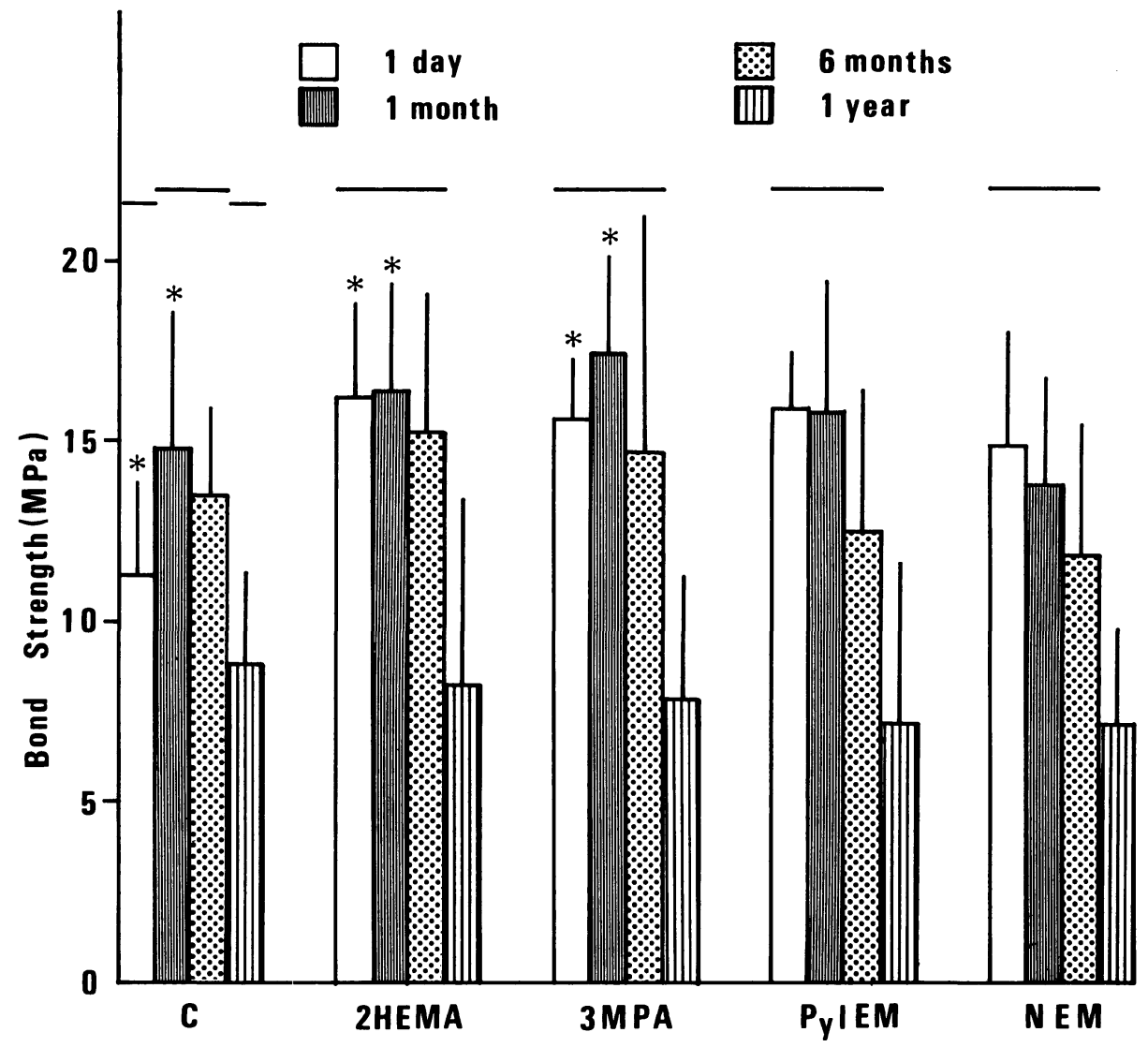

Fig. 2 Bond strength to dentin treated with the 10-3 solution. Bond strengths connected by bars were not significantly different. *Data of previous report ${ }^{4}$. 

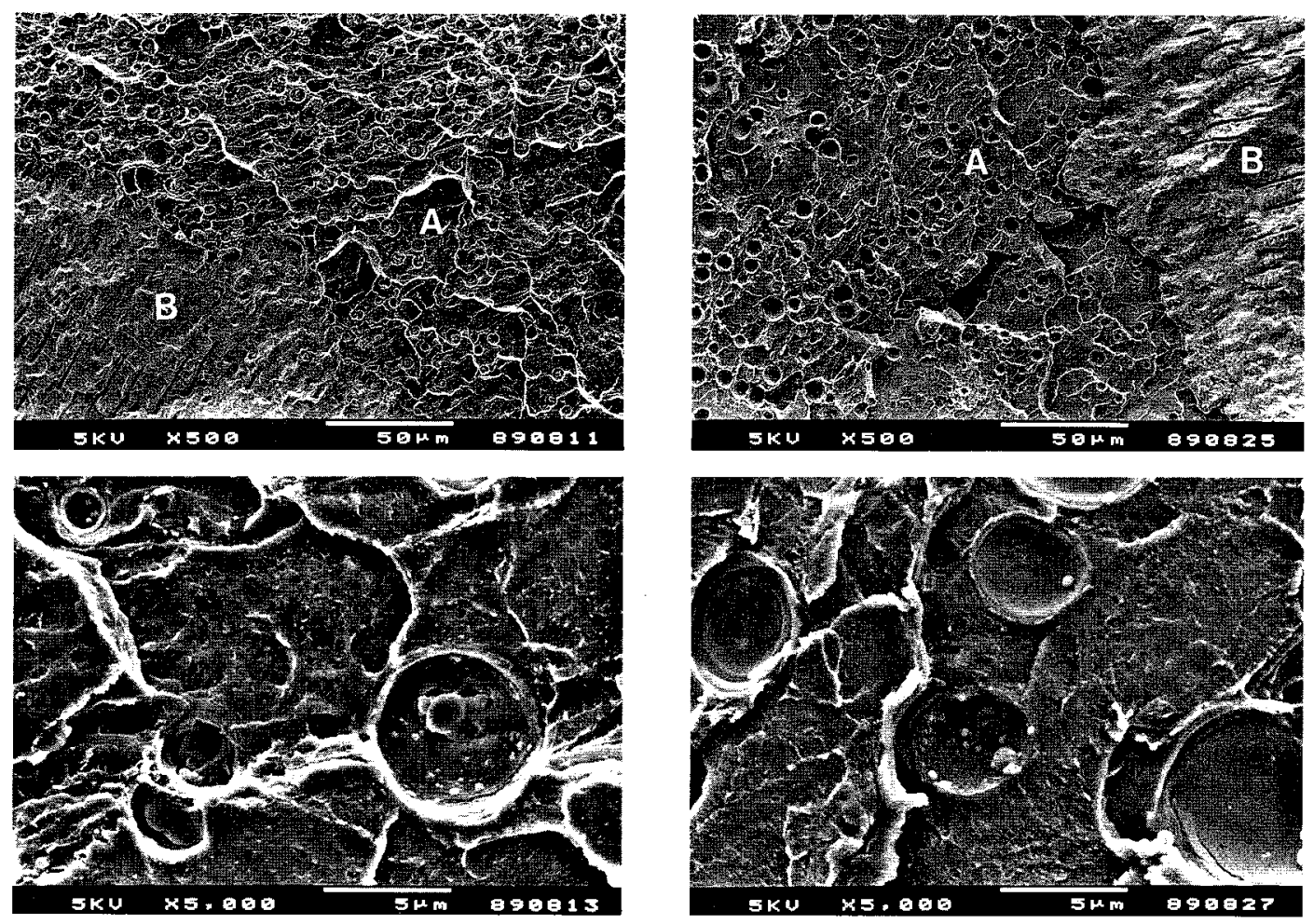

Fig. 3 SEM micrographs of typical fracture patterns on the dentin (left) and resin (right) surfaces of a specimen immersed for 1 day after tensile bond tests (A : showing resin cohesive fracture and $B$ : showing dentin cohesive fracture). The bottom micrographs show a magnified view of the area $(A)$ shown in the top micrographs.

interface failure and acid-proof dentin layer fractures.

\section{DISCUSSION}

In a previous paper ${ }^{4)}$, Fukushima et al. clearly confirmed the presence of an acid-proof dentin layer at an interface between a resin (MMA-TBB resin system) containing various methacrylates and dentin treated with 10-3 solution using a SEM and an electron-probe microanalyzer (EPMA). Furthermore, it was found that there was no significant relationship between the monomer structure and bond strength after 1 day and 30 days of immersion in water and the bond strength did not decrease with time.

Nakabayashi et $a l^{3}$. suggested that the decrease in bond strength in water for MMATBB resins containing hydrophilic monomers was greater than that for resins containing monomers with both hydrophilic and hydrophobic groups. They explained that the bond strength of the resins with hydrophilic monomers rapidly decreased as water degraded the hydrogen bond between the resins and dentin in a short time. We therefore applied four types of monomers with hydroxy, carboxyl, phenyl and naphthyl groups to investigate the effect of 

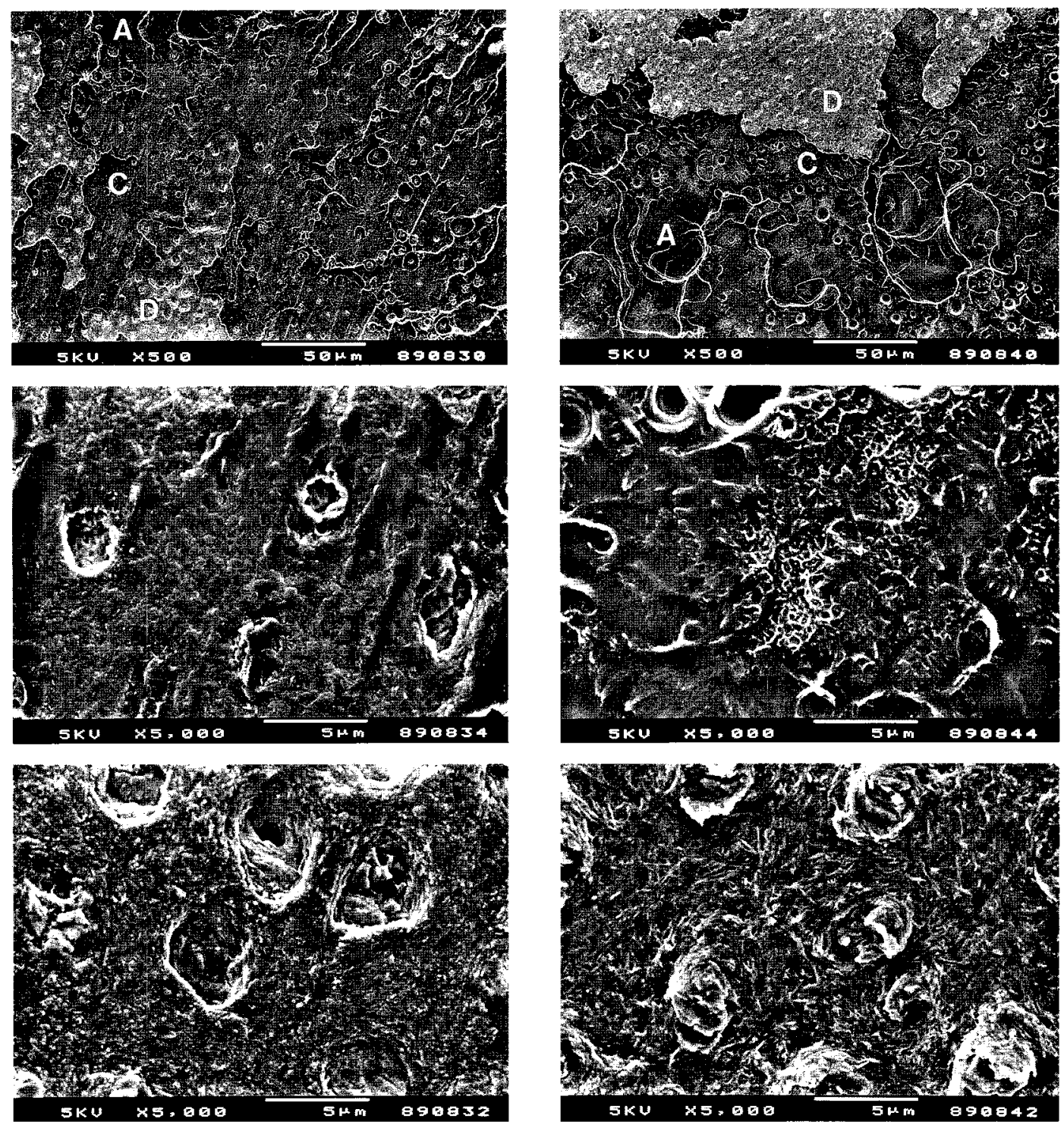

Fig. 4 SEM micrographs of typical fracture patterns on the dentin (left) and resin (right) surfaces of a specimen immersed for 1 year after tensile bond tests ( $\mathrm{A}$ : showing resin cohesive fractures, $\mathrm{C}$ : showing resin-dentin interface failure and $\mathrm{D}$ : showing acid-proof dentin layer fractures). The middle micrographs show a magnified view of the area $(\mathrm{C})$ shown in the top micrographs. The bottom micrographs show a magnified view of the area (D) shown in the top micrographs.

hydrophilic and hydrophobic groups in monomers on the decrease in bond strength in water over a long period of time. We expected that the decrease in bond strength in water for the resins containing hydrophobic monomers would be less than that for the other resins if the 
bond strength was reduced by long-term immersion in water.

However, although the bond strength of all the resins was greatly reduced by 1 year of immersion in water, there was no significant relationship between the monomer structure and the decrease in bond strength in water. In addition, there was no statistical difference in the bond strength among the monomers under all the various conditions although the bond strength was higher than that of the control after 1 day of immersion. The results indicate that the bond strength was mainly dependent upon the physical properties of the acid-proof dentin layer, which may be comparable for all resins under all conditions and the polymerization may be promoted by the addition of comonomers so that the bond strength was higher than that of the control after 1 day of immersion.

After the tensile bond tests, the fracture patterns on the dentin and resin surfaces of the specimens immersed for 1 year were different from those of the specimens immersed for 1 day. SEM micrographs revealed that the specimens immersed for 1 year had resin-dentin interface failure and acid-proof dentin layer fractures. Also, the collagen on the fractured acid-proof dentin layer surface was visible under a SEM. Kiyomura ${ }^{5)}$ reported that the decrease in bond strength of the 4-META/MMA-TBB resin system to dentin, which was treated with 10-3 solution, in water was mainly caused by the degeneration and swelling of collagen in the bottom acid-proof dentin layer. Kadoma and Imai ${ }^{10)}$ reported that the molecular weigth of the polymer (MMA-TBB resin) was higher inside than outside a collagen sheet where a proper quantity of ferric chloride and citric acid remained. We therefore suggest that the decrease in bond strength of all the resins was caused by either the degeneration and swelling of collagen or a difference in the degradation of the resin inside and outside the acid-proof dentin layer.

It however is unknown whether a similar result would be obtained when using a different bonding system. It is, therefore, necessary to further investigate the influence of water on the bonding of different bonding systems to dentin.

\section{CONCLUSIONS}

The bond strength of resins, containing 2-HEMA, 3MPA, PylEM and NEM, to dentin treated with the 10-3 solution was measured after being immersed in water at $37^{\circ} \mathrm{C}$ for 1 day, 1 month, 6 months and 1 year to investigate the influence of water on bonding and the relationship between the monomer structure and the decrease in bond strength in water.

The bond strength of the resins did not change with the time immersed in water up to 6 months, but decreased with any further increase in time. There was no significant relationship between the monomer structure and the decrease in bond strength in water.

SEM micrographs revealed that the specimens immersed for 1 day had resin cohesive fractures and dentin cohesive fractures, while the specimens immersed for 1 year had resin cohesive fractures, resin-dentin interface failure and acid-proof dentin layer fractures.

\section{REFERENCES}

1) Nakabayashi, N., Takeyama, M., Kojima, K. and Masuhara, E. : Studies on dental self-curing resins (19)-Adhesion of 4-META/MMA-TBB resin to pretreated dentin-, J Japan Soc Dent Appar Mat 
23(61) : 29-33, 1982. (in Japanese)

2) Nakabayashi, N., Takeyama, M., Kojima, K. and Masuhara, E. : Studies on dental self-curing resins (20)-Adhesion mechanism of 4-META/MMA-TBB resin to dentine-, J Japan Soc Dent Appar Mat 23(61) : 34-39, 1982. (in Japanese)

3) Nakabayashi, N., Yamashita, S., Kojima, K. and Masuhara, E.: Studies on dental self-curing resins (21)-Function of new monomers promoting adhesion to tooth substrates-, Rep Inst Medic Dent Eng 15 : 37-43, 1981. (in Japanese)

4) Fukushima, T., Inoue, $Y$. and Horibe, T.: Bonding of various methacrylates to dentin treated with $10 \%$ citric acid-3\% ferric chloride solution, $J$ J Dent Mater 7(4) : 592-598, 1988. (in Japanese)

5) Kiyomura, M. : Bonding strength to bovine dentin with 4-META/MMA-TBB resin-Long-term stability and influence of water-, $J$ J Dent Mater 6(6): 860-872, 1987. (in Japanese)

6) Fukushima, T., Miyazaki, K., Horibe, T. and Horie, K.: Application of functional monomers for dental use, Part 1, Synthesis and polymerization of functional monomers, J Fukuoka D C 4(1): 67-74, 1977. (in Japanese)

7) Kawaguchi, M., Fukushima, T., Miyazaki, K., Horibe, T., Habu, T. and Sawamura, N.: Synthesis and physical properties of polyfunctional methacrylates (Part-4). Synthesis and Physical properties of aromatic dimethacrylate copolymers, Dent Mater J 3(2): 272-279, 1984.

8) Nakamichi, I., Iwaku, M. and Fusayama, T. : Bovine teeth as possible substitutes in the adhesion test, $J$ Dent Res 62(10): 1076-1081, 1983.

9) Fukushima, T., Kawaguchi, M., Inoue, Y., Miyazaki, K. and Horibe, T.: Application of functional monomers for dental use (part-8) Adhesion of alkylene glycol monomethacrylates to etched enamel and dentin surfaces, Dent Mater J 3(1): 49-55, 1984.

10) Kadoma, Y. and Imai, Y.: Effect of ferric salts on polymerization of MMA by TBBO in the presence of a collagen sheet - A model to study the mechanism of adhesion of MMA resin to dentin-, $J J$ Dent Mater 7(5) : 817-823, 1988. (in Japanese) 


\title{
本号掲載論文の和文抄録
}

\author{
マイクロ波照射下での連続温度測定 \\ P. F. Hogan and T. Mori \\ シドニー大学歯学部歯科補緅学教室
}

マイクロ波による義歯作製法を検討する一手段とし て, マイクロ波照射下での連続温度測定を試みた。クロ メルーアルメル熱電対をインコネル細管中に封入するこ とにより, 熱電対への電磁波障害を除去することができ た。

フラスコ内の水 $(50 \mathrm{ml})$ の温度上昇を $500 \mathrm{~W}$ と $50 \mathrm{~W}$ の 条件下で測定し, 水銀温度計による測定の結果と比較し

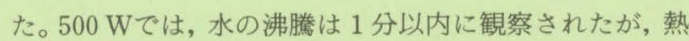
電対法により,約 45 秒に $100^{\circ} \mathrm{C}$ に達していることが明ら かとなった。 $50 \mathrm{~W} て ゙, 3$ 秒間のマイクロ波照射が 32 秒 の周期でおこり，加熱開始後約 6 分に $100^{\circ} \mathrm{C}$ を記録した か゚,これは短時間の照射のため肉眼観察や水銀温度計で はとらえられず，水の沸騰が観察されたのは，加熱開始 後約 10 分であった。

\section{各種メタクリレートの $10 \%$ エン酸ー $3 \%$ 塩化第二鉄溶液処理象牙質への 接着性に及ぼす水の影響について \\ 福島忠男, 堀部 隆 \\ 福岡歯科大学歯科理工学教室}

各種メタクリレートの $10 \%$ エン酸ー $3 \%$ 塩化第二 鉄溶液処理象牙質への接着性に及ほすす水の影響について 検討するために, $2 \mathrm{~mol} \%$ の親水性モノマー（2 HEMA， 3 MPA) および疎水性モノマー (PylEM, NEM) を含む 4 種の MMA-TBB 系レジンを調製し, 水 中浸漬 1 日, 1 力月, 6 力月, 1 年後に 30 秒間 $10-3$ 処 理した牛歯象牙質への接着力を測定した。さらに，モ， マーの構造と接着力の関係を検討した。

モノマーの構造と接着力の関係はいずれの条件でも顕
著に認められなかったが, 1 年後の接着力はいずれも著 しく減少していた。

1 日間水中浸漬した試料の接着力測定後の破壊パター ンは, 主にレジンやデンチンの凝集破壞であったが，1 年水中浸漬した試料の場合は, 接着界面の剝離や樹脂含 浸層の破壊が多く認められた。

従って, 接着力の減少は, 主に水による樹脂含浸層中の コラーゲンの脆弱化や樹脂含浸層内外のレンジの劣化の 差に基づくものと考えられる。

\section{In vitro における異なる表面性状の床用レジンへの細菌付着について 山内六男, 山本宏治*, 若林 学*, 川野襄二 朝日大学歯学部歯科補経学第 1 講座 \\ *朝日大学歯学部歯科保存学第 1 講座}

エメリペーパー400 番研磨，バフ研磨および表面滑沢 硬化処理を行った床用レジンへの Streptococci, Black- pigmented Bacteroides および Candida albicans の付着 について検討した。 